\section{Veterinaria México OA}

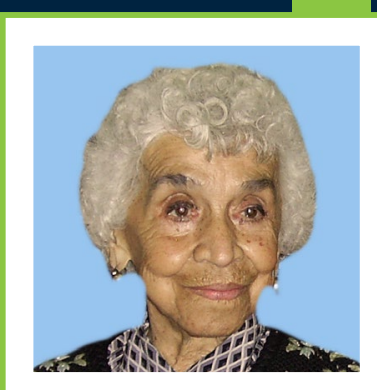

Aurora Velázquez Echegaray

De la Dra. Aurora Velázquez Echegaray destacan sus trabajos en rabia, newcastle, laringotraqueitis de las aves, brucelosis, toxoplasmosis, fiebre porcina clásica, gastroenteritis transmisible de los Cerdos, encefalitis equina venezolana, entre otros. Apoyó los trabajos de la Campaña Nacional para la erradicación de la Fiebre Aftosa, apuntalando la elaboración de los biológicos de calidad que permitieron controlar y eliminar esta enfermedad en México. Su contribución en investigación aplicada permitió el establecimiento de las técnicas de inmunofluorescencia, inhibición de migración de macrófagos, anticuerpos monoclonales y microscopía electrónica en el campo de la medicina veterinaria en México y Latinoamérica. La UNAM la nombró Profesora emérita en 1988.

'Departamento de Virología e Inmunología, Facultad de Medicina Veterinaria y Zootecnia, Universidad Nacional Autónoma de México, México

2 Director de la Granja Experimental Porcina y Avicola, Facultad de Medicina Veterinaria y Zootecnia, Universidad Nacional Autónoma de México, México
Veterinaria México OA

Publicación Digital de la Facultad de Medicina Veterinaria y Zootecnia

\title{
Relaciones antigénicas del virus de la bronquitis infecciosa de las aves con el de la gastroenteritis transmisible de los cerdos*
}

Juan José Romano P.

Aurora Velázquez E.'

Fernando Olguín R.2

\begin{abstract}
Comparasion of the FMVZ strain of transmisible gastroenteritis virus of pigs with the Massachusetts strain of infectious bronchitis virus of birds, revealed by neutralization, complement fixation and immunodifusion test, that there are antigenic relations between the two viruses.
\end{abstract}

\section{Resumen}

La comparación de la cepa FMVZ 69 del virus de la gastroenteritis transmisible de los cerdos, con la cepa Massachusetts del virus de la bronquitis infecciosa de las aves, mediante pruebas de neutralización, fijación de complemento e inmunodifusión reveló que existen relaciones antigénicas entre ambos virus.

Cite this as:

Este trabajo fue presentado como tesis profesional para obtención del título de Médico Veterinario Zootecnista del primer autor.

Romano P. JJ, Velázquez E. A, Olguín R. F. Relaciones antigénicas del virus de la bronquitis infecciosa de las aves con el de la gastroenteritis transmisible de los cerdos. Veterinaria México. 1975;6(2):38-47.

\section{Publicado: 2020-09-30}

Información y declaraciones adicionales en la página 13

() Derechos de autor:

Juan José Romano P. et al. 2020

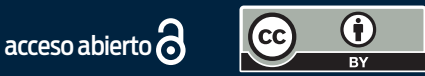

Romano P. JJ, Velázquez E. A, Olguín R. F. Relaciones antigénicas del virus de la bronquitis infecciosa de las aves con el de la gastroenteritis transmisible de los cerdos. Veterinaria México OA. 2020:7(3). doi: 10.22201/fmvz.24486760e.2020.3.927 


\section{Introducción}

Las relaciones morfológicas de los diferentes tipos de virus, su multiplicación en las células y sus semejanzas fisicoquímicas, hacen posible que se clasifiquen por grupos. ${ }^{1}$ El término coronavirus ha sido adoptado como nombre genérico para un grupo de virus cuyas diferentes propiedades se caracterizan por ser partículas víricas pleomórficas con un diámetro que oscila entre 80-160 nanómetros y están cubiertas por proyecciones en forma de rayos de 20 nanómetros de longitud, dando la apariencia de una "corona" de la que proviene el nombre. ${ }^{1}$ Se ha observado también como característica común, el acúmulo de virus en vacuolas citoplasmáticas. ${ }^{14}$ Con respecto a su composición química se ha demostrado mediante estudios citoquímicos en ratones, aves y cerdos que el genoma está compuesto por ácido ribonucleico. ${ }^{1}$ Dentro de este grupo se han clasificado los virus de:

- Bronquitis infecciosa de las aves.

1. Coronavirus humano.

1 Gastroenteritis transmisible de los cerdos.

- Hepatitis de los ratones.

1 Encefalomielitis hemoaglutinante de los cerdos.

La comparación de las características del virus de bronquitis infecciosa de las aves (BI), que es considerado como prototipo de este grupo, con el virus de gastroenteritis transmitible de los cerdos (GET) nos muestran ciertas analogías, ${ }^{1-3}$ que inducen a pensar en alguna posible relación mas estrecha entre ambos virus.

\begin{tabular}{|l|c|c|}
\hline \multicolumn{1}{|c|}{ Característica } & \multicolumn{2}{|c|}{ Virus } \\
\hline Diámetro & BI & GET \\
& $80-160 \mathrm{~nm}$ & $80-160 \mathrm{~nm}$ \\
\hline Estabilidad a temperatura ambiente & 1 hora & 3 días \\
\hline Ácido resistencia & $(+)$ & $(+)$ \\
\hline Sensibilidad al éter & $(+)$ & $(+)$ \\
\hline Fotosensibilidad & No hay informe & $(+)$ \\
\hline Sensibilidad al formaldehido & $(+)$ & $(+)$ \\
\hline Composición química del genoma & ARN & ARN \\
\hline Periodo de incubación & $18-24 \mathrm{~h}$ & $18-24 \mathrm{~h}$ \\
\hline
\end{tabular}

El propósito de este trabajo es establecer si existen o no relaciones antigénicas entre el virus de la bronquitis infecciosa de las aves y el virus de la gastroenteritis transmisible de los cerdos, mediante pruebas de seroneutralización en lechones susceptibles a GET y embriones de pollo, así como pruebas de inmunodifusión y fijación de complemento. 


\section{Material y métodos}

\section{Materiales}

Virus de gastroenteritis transmisible de los cerdos, cepa FMVZ, aisladas de un brote de campo en $1969 .{ }^{16}$ Proporcionado en forma de suspensión al 10\% en solución de Hank de intestino de lechón y que representa el décimo pase en cerdos susceptibles.

Virus de la bronquitis infecciosa de las aves, cepa Massachusetts, proporcionada por el Dr. R. Pérez Ravelo (Pérez Ravelo R, Laboratorios Serva, México, D.F.), en forma de líquido amnicalantoideo, ignorándose el número de pases en embrión de pollo.

Embriones de pollo de 9 días de edad.

Lechones susceptibles a GET de 7 días de edad.

Conejos de la raza Nueva Zelanda.

\section{Métodos}

A) Titulación de los virus de gastroenteritis transmisible de los cerdos y bronquitis infecciosa de las aves

Titulación del virus de gastroenteritis transmisible

Dieciséis lechones de 7 días de edad se alojaron individualmente en unidades Horsffal durante 3 días y fueron alimentados con una dieta que sustituía a la leche materna (leche de vaca en polvo y dextrosa, esterilizados a 110 libras por 15 minutos). Al cuarto día los animales se dividieron al azar en cuatro grupos de cuatro lechones cada uno y fueron inoculados oralmente con las diluciones del virus $10^{-5} 10^{-6} 10^{-7} 10^{-8}$ de la suspensión original del virus, proporcionando 1 $\mathrm{ml}$ por lechón.

Los animales fueron observados diariamente durante 5 días, anotándose los signos clínicos y las lesiones macroscópicas a la necropsia. Los signos de diarrea profusa de color blanco amarillento, deshidratación y muerte; así como las lesiones de estómago con leche cuajada, intestino traslúcido con líquido y gas, ausencia de quilo en vasos linfáticos, mesentéricos y atrofia de las vellosidades intestinales, fueron indicativos de infección.

Para encontrar la dosis infectante lechón 50\% (DIL 50\%) se aplicó el método de Reed y Muench citado por Cunningham. ${ }^{5}$

\section{Titulación del virus de bronquitis infecciosa}

La suspensión original del virus se diluyó $10^{-1}$ a $10^{-9}$ en caldo triptosa estéril, inoculando $0.2 \mathrm{ml}$ de cada dilución a 4 embriones de pollo de 9 días de edad. Según la técnica descrita por Cunningham. ${ }^{5}$ La inoculación se hizo en la cavidad alantoidea y una vez inoculados se llevaron a la incubadora manteniéndose a 37 ${ }^{\circ} \mathrm{C}$ con $60 \%$ de humedad, observándose cada 24 h por ovoscopia y desechándose los embriones que murieron en las primeras $24 \mathrm{~h}$. Al séptimo día postinoclación se sacrificaron los sobrevivientes refrigerándolos durante $4 \mathrm{~h}$.

Posteriormente se observaron para determinar lesiones como: enanismo, retorcimiento del cuello, dedos deformados y comprensión de la cabeza con el cuerpo; considerándolos así como infectados..$^{15}$ 
Para obtener la dosis infectante embrión 50\% (DIE 50\%) se aplicó el mismo procedimiento descrito para la titulación del virus de GET.

b) Preparación de sueros hiperinmunes contra el virus de gastroenteritis transmisible y de bronquitis infecciosa

Para la preparación de ambos sueros se utilizaron 4 conejos de la raza Nueva Zelanda, clínicamente sanos y que nunca antes habían sido inoculados.

Preparación del suero hiperinmune contra gastroenteritis transmisible

La suspensión original del virus fue utilizada como antígeno en dos conejos, los que fueron inoculados con $2 \mathrm{ml}$ por vía subcutánea cada tercer día. Después de 6 inoculaciones se tomó una muestra sanguínea de la vena marginal de la oreja poniéndose en contacto el suero obtenido con el antígeno, en una prueba Ouchterlony ${ }^{8}$ como se observó muy ligera precipitación, se realizaron 2 inoculaciones más, después de las cuales se produjo una precipitación franca, con lo que los conejos fueron sangrados en blanco por punción cardiaca. La sangre fue depositada asépticamente en tubos de centrifuga refrigerada durante $4 \mathrm{~h}$ y el suero obtenido, congelado a $-20^{\circ} \mathrm{C}$ hasta su uso.

Preparación del suero hiperinmune contra bronquitis infecciosa

La suspensión original del virus fue inoculada en embriones de pollo de 9 días de edad en la cámara alantoidea, a la dosis de $0.2 \mathrm{ml}$ por embrión; 30 h después, se cosechó el líquido alantoideo que se considera que posee la mayor concentración del virus. ${ }^{15}$ Este líquido sirvió como antígeno para la inoculación de dos conejos, los cuales fueron inoculados de la misma manera que los utilizados en la preparación del suero hiperinmune contra el virus GET va obteniéndose después de 6 inoculaciones una precipitación franca en la prueba de Ouchterlony, por lo que se hizo el sangrado de los conejos por punción cardiaca, y el suero se almacenó en congelación a $-20{ }^{\circ} \mathrm{C}$ hasta su uso.

\section{c) Absorción de los sueros hiperinmunes}

Una vez obtenidos los sueros hiperinmunes contra ambos antígenos, éstos fueron absorbidos con intestino normal de lechón y líquido alantoideo normal de embrión de pollo, según la técnica descrita por Kabat y Mayer. ${ }^{12}$

\section{d) Pruebas de fijación de complemento}

Titulación de complemento y hemolisina

Se utilizo hemolisina de tipo comercial (Bacto Antishepp Hemolysin Glicerinated, Laboratories Detroit, Michigan, EUA [DIFCO]) titulada según la técnica utilizada por Herbert ${ }^{11}$ y modificada por Fraire (Fraire Cachón Moises, Laboratorio de Virología, FMVZ); un complemento comercial (Guinea Pig, Complement, Baltimore Biological Laboratory Maryland, Gelman Instrument Company, Michigan, EUA), que en forma simultánea fue titulado con la hemolisina según la técnica utilizada por Herbert y modificada por Fraire. 
Prueba de fijación de complemento

Para esta prueba se utilizó la técnica en caja descrita por Herbert y modificada por Fraire, enfrentando virus de bronquitis infecciosa con un antisuero homólogo y un antisuero heterólogo (anti-GET). De la misma forma el virus de gastroenteritis transmisible se enfrentó con un antisuero homologo y un antisuero heteró$\log$ (anti-BI).

\section{e) Pruebas de inmunifución en placa}

Se utilizó la prueba de inmunodifusión en agar del tipo "Cuchterlony"8 empleando equipo Gelman para microtécnica y aplicando el diseño de precipitación descrito por Darbyshire. ${ }^{6}$

\section{f) Pruebas de seroneutrolización en embrión de pollo}

Para la evaluación de la neutralización del virus de bronquitis infecciosa, con anticuerpos antigastroenteritis transmisible y antibronquitis infecciosa, se utilizaron embriones de pollo como indicador.

Siguiendo el método de seroneutrolización "virus constante, suero decreciente"; ${ }^{5}$ se prepararon las siguientes diluciones de ambos sueros 1:2 1:4 1:8, y se agregaron éstas a una suspensión de virus de bronquitis infecciosa titulado a 250 DIE 50\% por ml. Las mezclas suero-virus se incubaron durante 30 minutos a 37 ${ }^{\circ} \mathrm{C}$ en la obscuridad y se inocularon a la dosis de $0.2 \mathrm{ml}$ por embriones en 8 lotes de 5 embriones cada uno, quedando agrupados de la siguiente forma:

Lote 1. Cinco embriones sin inocular utilizados como testigos.

Lote 2. Cinco embriones inoculados en la cavidad alantoidea con virus de BI conteniendo 250 DIE $50 \%$ sin suero.

Lote 3. Cinco embriones inoculados en la cavidad alantoidea con una mezcla de virus con BI (250 DIE 50\%) más suero homólogo, anti BI, diluido 1:2.

Lote 4. Cinco embriones inoculados en la cavidad alantoidea con una mezcla de virus con BI (250 DIE 50\%) más suero homólogo, anti BI, diluido 1:4.

Lote 5. Cinco embriones inoculados en la cavidad alantoidea con una mezcla de virus con BI (250 DIE 50\%) más suero homólogo, anti BI, diluido 1:8.

Lote 6. Cinco embriones inoculados en la cavidad alantoidea con una mezcla de virus con BI (250 DIE 50\%) más suero heterólogo, anti GET, diluido 1:2.

Lote 7. Cinco embriones inoculados en la cavidad alantoidea con una mezcla de virus con BI (250 DIE 50\%) más suero heterólogo, anti GET, diluido 1:4.

Lote 8. Cinco embriones inoculados en la cavidad alantoidea con una mezcla de virus con BI (250 DIE 50\%) más suero heterólogo, anti GET, diluido 1:8.

Una vez hecha la inoculación, los embriones se llevaron a la incubadora y se ovoscopiaron cada 24 horas desechándose los embriones que murieron en las primeras 24 horas. Al séptimo día posinoculación, se sacrificaron los embriones sobrevivientes buscando lesiones típicas de bronquitis infecciosa. Se calculó después el punto final de neutralización por el metodo de Reed y Muench citado por Cunningham. ${ }^{5}$ 


\section{g) Pruebas de seroneutralización en lechones susceptibles}

Para la evaluación de neutralización del virus de GET, con anticuerpos homólogos y heterólogos (anti-BI), se utilizaron lechones como indicador; tomando para todos cantidades constantes de virus (100 DIL 50\%).

Los lechones fueron divididos al azar en 3 lotes:

Lote 1. Dos lechones como control, inoculados por vía oral con $2 \mathrm{ml}$ de virus de GET (100 DIL 50\%) (previamente incubado en la obscuridad a $37{ }^{\circ} \mathrm{C}$ por 30 minutos).

Lote 2. Dos lechones inoculados por vía oral con una mezcla a volúmenes iguales y previamente incubada en la oscuridad a $37^{\circ} \mathrm{C}$ durante 30 minutos, de virus de GET (100 DIL 50\%) más suero homólogo, anti-GET sin diluir.

Lote 3. Dos lechones inoculados por vía oral con una mezcla a volúmenes iguales y previamente incubada en la oscuridad a $37^{\circ} \mathrm{C}$ durante 30 minutos, de virus de GET (100 DIL 50\%) más suero heterólogo, anti-BI sin diluir.

Estos lechones fueron alojados individualmente en unidades Horsffal y alimentados con una dieta artificial descrita anteriormente. Los animales se observaron diariamente durante 5 días para determinar la presencia de síntomas de gastroenteritis transmisible. Al quinto día fueron sacrificados por electroshock, haciéndose la necropsia de éstos y buscando lesiones típicas de gastroenteritis transmisible.

\section{Resultados}

Los resultados de la titulación de ambos virus se expresan en los Cuadros 1 y 2. El virus de la gastroenteritis transmisible cepa FMVZ 69 reveló tener un título de 6.2 DIL 50\% ml. El virus de la bronquitis infecciosa de las aves tuvo un titulo de 7.7 DIE $50 \% 0.2 \mathrm{ml}$.

Tanto el virus GET como BI fijaron el complemento en forma clara al reaccionar con sus sueros homólogos y heterólogos como se puede ver en el Cuadro 3 , en el que se describe la prueba lenta y se expresan las lecturas obtenidas en el espectrofotómetro.

El virus de la bronquitis infecciosa fue neutralizado con un suero antigastroenteritis transmisible como se puede comprobar en el Cuadro 4, en el que se observa que la infección de los embriones de pollo por el virus disminuyó en un $10^{-0.94}$ cuando se mezcló con el suero antigastroenteritis transmisible y que es muy semejante a la neutralización observada con el suero homólogo $10^{-1.15}$.

El virus de la gastroenteritis transmisible se mezcló con un suero antibronquitis infecciosa; esta mezcla fue inoculada a lechones susceptibles y se observó una disminución en la mortalidad, un periodo de incubación muy largo y signos muy benignos de la enfermedad, tal como sucedió al inocular lechones susceptibles con la mezcla de virus GET y suero homólogo. Estos resultados pueden observarse en el Cuadro 5. 
Cuadro 1. Titulación del virus de gastroenteritis transmisible de los cerdos, en lechones susceptibles de 7 días de edad ${ }^{\mathrm{a}}$

\begin{tabular}{|c|c|c|c|c|c|c|c|}
\hline \multirow{2}{*}{$\begin{array}{c}\text { Número } \\
\text { Animales }\end{array}$} & $\begin{array}{c}\text { Dilución del } \\
\text { virus inoculado }\end{array}$ & \multicolumn{4}{|c|}{} & \multirow{2}{*}{ Lesiones al finalizar la prueba } \\
\cline { 3 - 8 } & & $\mathbf{2 4} \mathbf{h}$ & $\mathbf{4 8} \mathbf{h}$ & $\mathbf{7 2} \mathbf{h}$ & $\mathbf{9 6} \mathbf{h}$ & $\mathbf{1 2 0} \mathbf{h}$ & \\
\hline 4 & $10^{-5}$ & $4 / 4$ & $4 / 4$ & $4 / 4$ & $4 / 4$ & $4 / 4^{\mathrm{b}}$ & Atrofia de vellosidades intestinales \\
\hline 4 & $10^{-6}$ & $1 / 4$ & $2 / 4$ & $2 / 4$ & $2 / 4$ & $2 / 4$ & Atrofia de vellosidades intestinales \\
\hline 4 & $10^{-7}$ & $1 / 4$ & $1 / 4$ & $1 / 4$ & $1 / 4$ & $1 / 4$ & Intestino lleno de líquido amarillo y gas \\
\hline 4 & $10^{-8}$ & $0 / 4$ & $0 / 4$ & $0 / 4$ & $0 / 4$ & $0 / 4$ & Ninguna \\
\hline
\end{tabular}

${ }^{a}$ Los animales fueron inoculados oralmente después de haber sido alimentados durante 72 horas con una dieta artificial y alojados individualmente en unidades Horsffal.

b El numerador representa el número de animales inoculados.

El denominador representa el número de animales con signos de enfermedad.

Cuadro 2. Titulación del virus de bronquitis infecciosa de las aves

(cepa Massachusetts) en embrión de pollo de 9 días de edad

Título $=7.7$ dosis infectante embrión 50\%/0.2 ml

(DIE $50 \% / 0.2 \mathrm{ml}$ )

Cuadro 3. Relaciones antigénicas entre el virus de bronquitis infecciosa y el virus de gastroenteritis transmisible estudiadas mediante fijación de complemento con sueros hiperinmunes homólogos y heterólogos ${ }^{\mathrm{a}}$

\begin{tabular}{|c|c|c|c|}
\hline \multicolumn{4}{|c|}{ Dilución del suero anti-GET } \\
\hline & $\mathbf{1 : 1 0}$ & $\mathbf{1 : 2 0}$ & $\mathbf{1 : 4 0}$ \\
\hline $1: 40$ & $85 \%{ }^{\mathrm{b}}$ & $80 \%$ & $30 \%$ \\
\hline $1: 20$ & $80 \%$ & $30 \%$ & $25 \%$ \\
\hline $1: 10$ & $25 \%$ & $15 \%$ & $12 \%$ \\
\hline $1: 5$ & $10 \%$ & $0 \%$ & $0 \%$ \\
\hline
\end{tabular}

\begin{tabular}{|c|c|c|c|}
\hline \multicolumn{4}{|c|}{ Dilución del suero anti-BI } \\
\hline & $\mathbf{1 : 1 0}$ & $\mathbf{1 : 2 0}$ & $\mathbf{1 : 4 0}$ \\
\hline $1: 40$ & $97 \%$ & $90 \%$ & $85 \%$ \\
\hline $1: 20$ & $93 \%$ & $85 \%$ & $80 \%$ \\
\hline $1: 10$ & $90 \%$ & $83 \%$ & $78 \%$ \\
\hline \multicolumn{4}{|c|}{ Dilución del virus GET } \\
\hline
\end{tabular}

\begin{tabular}{|c|c|c|c|}
\hline \multicolumn{4}{|c|}{ Dilución del suero anti-GET } \\
\hline & $1: 10$ & $1: 20$ & $1: 40$ \\
\hline $1: 10$ & $55 \%$ & $40 \%$ & $30 \%$ \\
\hline
\end{tabular}

\begin{tabular}{|c|c|c|c|}
\hline \multicolumn{4}{|c|}{ Dilución del suero anti-BI } \\
\hline & $1: 10$ & $1: 20$ & $1: 40$ \\
\hline $1: 10$ & $97 \%$ & $92 \%$ & $88 \%$ \\
\hline
\end{tabular}

a Estos resultados corresponden a la prueba lenta.

b Estas cifras son representativas de las lecturas obtenidas en el espectrofotómetro. 
Cuadro 4. Neutralización del virus de bronquitis infecciosa por un suero antigastroenteritis transmisible utilizando embriones de pollo como indicador

\begin{tabular}{|c|c|c|c|}
\hline $\begin{array}{l}\text { Lote } \\
\text { número }\end{array}$ & Inóculo & $\begin{array}{l}\text { Número de } \\
\text { embriones }\end{array}$ & $\begin{array}{l}\text { Número de embriones con } \\
\text { lesiones típicas de BI a los } \\
7 \text { días posinoculación }\end{array}$ \\
\hline 1 & Testigo NO inoculado & 5 & 0 \\
\hline 2 & Virus BI (250 DIE 50\%) & 5 & 5 \\
\hline 3 & $\begin{array}{l}\text { Virus BI (250 DIE } 50 \%) \text { mezclado con suero anti BI diluido } \\
1: 2\left(10^{-0.7}\right)\end{array}$ & 5 & 0 \\
\hline 4 & $\begin{array}{l}\text { Virus BI (250 DIE 50\%) mezclado con suero anti BI diluido } \\
1: 4\left(10^{-1}\right)\end{array}$ & 5 & 2 \\
\hline 5 & $\begin{array}{l}\text { Virus BI (250 DIE 50\%) mezclado con suero anti BI diluido } \\
1: 8\left(10^{-1.3}\right)\end{array}$ & 5 & 3 \\
\hline 6 & $\begin{array}{l}\text { Virus BI ( } 250 \text { DIE } 50 \%) \text { mezclado con suero anti GET } \\
\text { diluido } 1: 2\left(10^{-7.0}\right)\end{array}$ & 5 & 0 \\
\hline 7 & $\begin{array}{l}\text { Virus BI ( } 250 \text { DIE 50\%) mezclado con suero antivirus BI } \\
\text { (250 DIE 50\%) }\end{array}$ & 5 & 3 \\
\hline 8 & Mezclado con suero anti GET diluido 1:8 $\left(10^{-1.3}\right)$ & 5 & 5 \\
\hline
\end{tabular}

Neutralización 50\% de 250 DIE 50\% se encuentra en la dilución del suero antibronquitis Infecciosa. $10^{-1.15}$
Neutralización 50\% de 250 DIE 50\% se encuentra en la dilución del suero antigastroenteritis transmisible.

$10^{-0.94}$

Cuadro 5. Neutralización del virus de gastroenteritis transmisible con un suero antibronquitis infecciosa utilizando lechones susceptibles como indicador

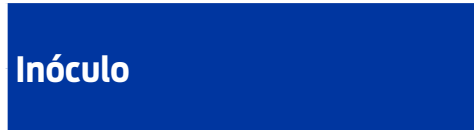

Virus GET $1 \mathrm{ml}$ (100 DIL 50\%)

Virus GET $1 \mathrm{ml}$ (100 DIL 50\%) con $1 \mathrm{ml}$ suero anti GET

Virus GET 1 ml (100 DIL 50\%) con $1 \mathrm{ml}$ suero anti-BI

\begin{tabular}{|c|c|c|c|c|c|}
\hline \multirow{2}{*}{$\begin{array}{c}\text { Número de animales } \\
\text { inoculados }\end{array}$} & \multicolumn{5}{|c|}{ Signos y lesiones típicas de GET } \\
\cline { 2 - 7 } & $\mathbf{2 4 h}$ & $\mathbf{4 8 h}$ & $\mathbf{7 2} \mathbf{h}$ & $\mathbf{9 6} \mathbf{h}$ & $\mathbf{1 2 0} \mathbf{h}$ \\
\hline 2 & $2 / 2$ & $2 / 2$ & $2 / 2$ & \multicolumn{3}{|c|}{ Muertos $^{\mathrm{a}}$} \\
\hline 2 & $0 / 2$ & $0 / 2$ & $1 / 2$ & $2 / 2$ & $2 / 2^{\mathrm{b}}$ \\
\hline 2 & $0 / 2$ & $0 / 2$ & $1 / 2$ & $2 / 2$ & $2 / 2^{\mathrm{b}}$ \\
\hline
\end{tabular}

a A estos animales se les hizo necropsia, encontrándose lesiones típicas y severas de GET.

b Enfermedad benigna. Los animales se sacrificaron a los 5 días postinoculación observándose en ellos las siguientes lesiones: intestino lleno de líquido amarillo y gas y ligera atrofia de vellosidades intestinales. 
Tomando como base el diseño de Darbyshire, ${ }^{6}$ se hicieron pruebas de precipitación en agar mediante la técnica de microplaca para observar la precipitación de ambos virus con sueros homólogos y heterólogos. El diseño consistió en 6 pozos dispuestos en forma circular y un séptimo pozo en el centro. Los dos ejes transversales prueban que los virus son precipitados por cualquiera de los sueros, sean homólogos o heterólogos. El diseño puede observarse en la Figura 1.

\section{Discusión}

El grupo de "coronavirus" se ha integrado como resultado de estudios químicos, físicos, citoquímicos y de observación en el microscopio electrónico de una serie de virus que producen enfermedades con sintomatología variada en diversas especies animales entre las que podemos citar al hombre, las aves, los cerdos y los ratones. ${ }^{1,14,18}$ Es interesante establecer si existe alguna relación de tipo antigénico entre los miembros de este grupo de virus. Los resultados de este estudio confirman los hallazgos de Bradburne y McIntosch ${ }^{4,13}$ que han encontrado, mediante pruebas de fijación de complemento, seroneutralización, inmunodifusión e inmunofluorescencia, reacciones cruzadas entre cepas de corona virus humano y cepas del virus de la hepatitis en ratones. Melntosh, al realizar estas pruebas enfrentando los virus de la hepatitis de los ratones y cepas de coronavirus humano, con el virus de la bronquitis infecciosa de las aves (cepa Beaudette), no informó resultados determinantes al respecto.

En este trabajo las pruebas de fijación de complemento revelaron que el suero hiperinmune antibronquitis infecciosa reaccionó en forma positiva con el antígeno del virus de la gastroenteritis transmisible desde la dilución 1:10. El suero hiperinmune antigastroenteritis transmisible no reaccionó con el antígeno del virus de la bronquitis infecciosa sino hasta la dilución 1:40; la observación de las primeras diluciones de este mismo suero hiperinmune al reaccionar con su antígeno homólogo y heterólogo podría interpretarse como negativas; sin embargo, al realizar una posterior titulación en la que se diluyeron los antígenos, se observó una marcada fijación del complemento desde la dilución 1:20 del antígeno y con las mismas diluciones del suero, lo que induce a pensar en un fenómeno de zona.

Las pruebas de neutralización, utilizando embriones de pollo como indicador, revelaron que el suero anti-GET es capaz de neutralizar al virus de bronquitis infecciosa a la dilución $10^{-0.9}$ (suero diluido $>1: 2$ pero $<1: 4$ ) lo cual es casi semejante al título de suero homólogo (anti-BI) que tuvo un título ligeramente mayor de 1:4 $\left(10^{-1.1}\right)$.

Por la dificultad de conseguir animales axénicos en nuestro medio, para el desarrollo de las pruebas de seroneutralización se utilizaron lechones convencionales de 7 días de edad que se alojaron en unidades Horsffal y fueron alimentados con una dieta artificial durante 3 días, considerando que los anticuerpos proporcionados por el calostro son eliminados de la pared intestinal a las 48 horas de ser ingeridos y que los lechones son altamente susceptibles al virus de la gastroente- 


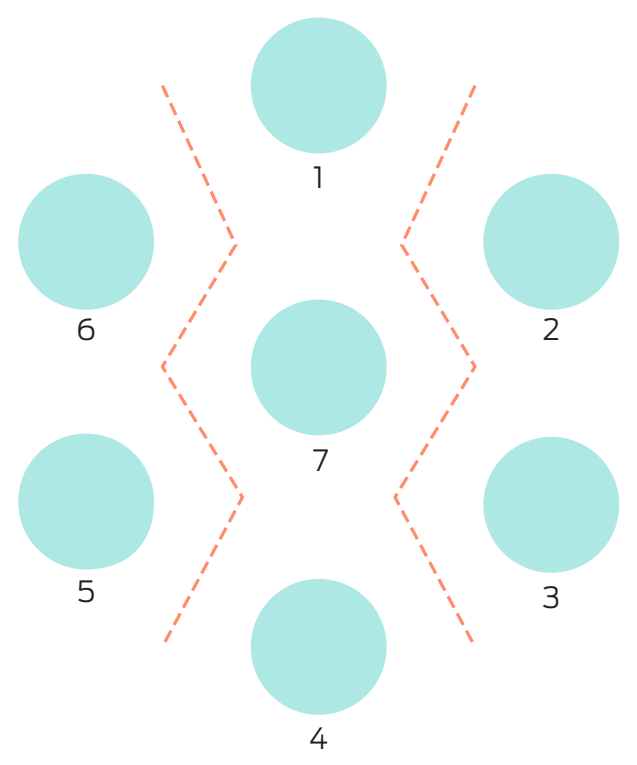

Figura 1. Diseño para probar la relación antigénica entre el virus de bronquitis infecciosa de las aves y el virus de gastroenteritis transmisible de los cerdos. Adaptado del diseño original de Darbyshire. ${ }^{6}$ 1) Virus GET; 2) suero anti-GET; 3) suero anti-Bl; 4) virus $\mathrm{GET}$; 5) suero anti-GET; 6) suero anti-Bl; 7) virus BI. Las líneas indican el sitio sonde teóricamente se observaría la precipitación en caso de existir relaciones antigénicas entre ambos virus.

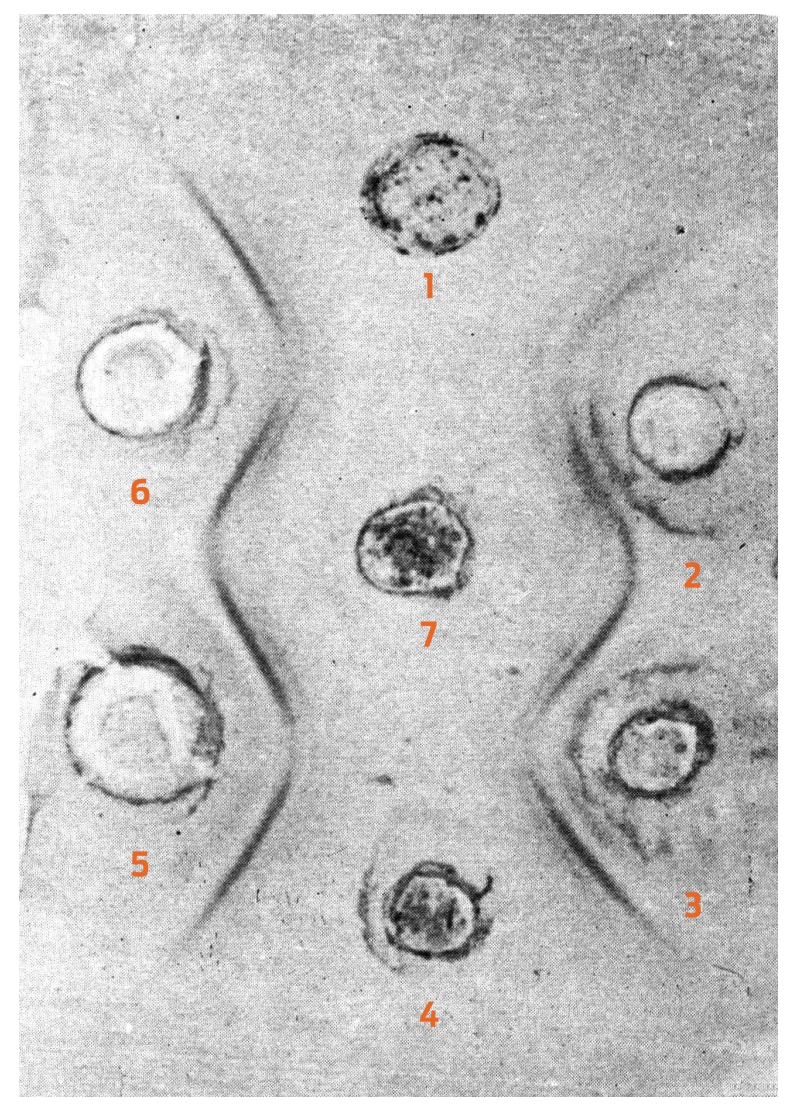

Figura 2. Resultado de las pruebas de inmunodifusión para establecer las relaciones antigénicas entre el virus de gastroenteritis transmisible de los cerdos. Se conservó la misma distribución indicada en la Figura 1. Las líneas observadas indican la relación antigénica que existe entre ambos virus. 
ritis transmisible, ${ }^{7}$ se procedió a la realización de esta prueba, tomando un lote como testigo del poder infectante del virus.

El suero antibronquitis infecciosa neutralizó el virus de la gastroenteritis transmisible que contenía 100 DIL 50\% ml cuando se mezcló a volúmenes iguales y sin diluir. En este caso no fue posible establecer el título de neutralización de cada suero, ya que no se obtuvo el número suficiente de lechones susceptibles para lograr este resultado. Las características de la enfermedad de la gastroenteritis transmisible en lechones hacen también prácticamente imposible el establecer el título de neutralización, ya que numerosos investigadores al hacer seroneutralización del virus con sueros homólogos obtienen signos muy benignos acompañados con lesiones típicas de la enfermedad. ${ }^{7,10,19,20}$ En este caso tanto con el suero homólogo (anti-GET) como con el heterólogo (anti-BI) se observó una enfermedad muy benigna con un largo periodo de incubación (5 días). Al sacrificar estos lechones por el electroshock se observó en la necropsia ligera atrofia de las vellosidades intestinales del yeyuno.

$\mathrm{Al}$ enfrentar los virus de la bronquitis infecciosa o la gastroenteritis transmisible con sus respectivos sueros (homólogos y heterólogos) en prueba de inmunodifusión se observó que el suero hiperinmune anti-GET reaccionaba con ambos antígenos, formando bandas de precipitación que indicaban un exceso de antígeno, lo que ratificó el fenómeno de zona revelado en las pruebas de fijación de complemento; se procedió entonces a realizar diluciones del virus de la bronquitis infecciosa y de la gastroenteritis transmisible; observándose entonces que el suero anti-GET reaccionaba con ambos en forma determinante en las diluciones del virus 1:20.

Los sueros hiperinmunes fueron absorbidos según la técnica descrita por Kabat y Mayer ${ }^{12}$ eliminando así la posibilidad de obtener resultados falsos al enfrentarse estos sueros con las suspensiones originales del virus.

Doyle y Harada ${ }^{7,10}$ informaron que no existen variantes antigénicas del virus de GET al comparar cepas procedentes de diferentes países. El primer aislamiento del virus de GET en México se corroboró por medio de neutralización con un suero hiperinmune procedente de Estados Unidos, ${ }^{16}$ lo que hace pensar que la cepa mexicana se comporta igual que las del resto del mundo, confirmándose así los informes de Doyle y Harada. Por lo que se refiere al virus BI, se han aislado varias cepas con variantes antigénicas; ${ }^{17}$ en este trabajo se utilizó la cepa Massachussets, por ser la que tiene un mosaico antigénico más amplio, además de encontrarse presente en más del $50 \%$ de los brotes del campo. ${ }^{17}$

Es importante que se realicen otras investigaciones para establecer las relaciones antigénicas existentes entre el virus de la gastroenteritis transmisible y las diferentes cepas del virus de la bronquitis infecciosa, ya que este trabajo únicamente establece la relación que existe con la cepa Massachussets.

Algunos médicos veterinarios han observado que en brotes de campo en donde la población de aves y cerdos es muy densa, aparecen en forma simultánea la gastroenteritis transmisible en cerdos y la bronquitis infecciosa en aves (Galindo R., Fernando, comunicación personal, 1973; Villaseñor V., Rodolfo, comunicación personal; 1973). Investigaciones no publicadas que se llevan a cabo 
actualmente en el Laboratorio de Virología de la Facultad de Medicina Veterinaria y Zootecnia de la UNAM han revelado que la inoculación oral del virus de la bronquitis infecciosa a lechones susceptibles produce una enfermedad con signos y lesiones típicas de GET. Estos dos hechos y los resultados de este trabajo hacen pensar en una relación mucho muy estrecha entre ambos virus.

Los trabajos de Bradburne y McIntosch, 4,13 junto con los resultados de esta investigación, conducen a la suposición de que existe un antígeno común del grupo de los "coronavirus". Se podría pensar también que algunos virus que no están clasificados dentro de este grupo, pero que producen enfermedades semejantes, pudieran en el futuro clasificarse dentro del grupo, si sus características físicas, químicas y biológicas lo ameritasen. Nos referimos particularmente al virus de la diarrea letal infantil de los ratones, que al igual que el de la gastroenteritis transmisible de los cerdos produce una gran mortalidad entre los recién nacidos, con atrofia de las vellosidades intestinales. ${ }^{1}$ 


\section{Referencias}

1. Andrewes OH. Virus of vertebrates, 3th ed. Londres: Baillere Tidall and Cox; 1972.

2. Bohl EH. Transmissible gastroebteritis in diseases of swine. Dunne HW, editor, 3th ed. Ames, Iowa: The Iowa University Press; 1970.

3. Biester HE, Shwarte LH. Enfermedades de las aves. México: UTEHA; 1964.

4. Bradburne AF. Antigenic relationships against Coronavirues. Arch Ges Virus Forsch. 1970;31:352-64. Citado en: The Veterinary Bulletin 1971;41:1124.

5. Cunningham HC. Virología práctica, 6 ed. Madrid: Acribia; 1971.

6. Darbyshire JH. Agar gel diffusion studies with a mucosal disease of cattle. Res Vet Sci. 1962;3:118-28.

7. Doyle IP, Hutchings LM. A transmissible gastroenteritis in pigs. JAVMA. 1946;108:257-9.

8. Gelman procedures, techniques and apparatus for electrophoresis, Michigan: Gelman Instrument Company; 1968.

9. Haelterman EO, Hooper BE. Transmissible gastroenteritis of swine as a model for the study of enteric disease. Gastroenterology. 1967;53:109-13.

10. Harada K, Kumagai T, Sasahara J. Studies in transmissible gastroenteritis in pigs. Nat Inst Anim Hlih Quart. 1967;7:127-37.

11. Herbert WJ. Veterinary inmunology. Oxford-Edinburgh: Blackwell Scientific Publications; 1970.

12. Kabat EA, Mayer MM. Experimental immunochemistry. Springfield, Illinois: Charles C. Thomas Publisher; 1948.

13. McIntosch K, Kapikiam AZ, Hardisson KA, Hartley JW, Chanock RM. Antigenic relationships among the coronaviruses of man and between human and animal coronaviruses. J Immunol. 1969;102:1109-18.

14. Mengelin WL, Boothe AD, Ritchie AE. Characteristics of a coronavirus (strain 67 N) of pigs. A J Vet Res. 1972;33:297-308.

15. Methods for examination of poultry biologics National Academy of Sciences. Washington, DC: Nat Res Council; 1963.

16. Olguín RF. Aislamiento del virus de gastroenteritis transmisible de los cerdos. Veterinaria México. 1970;2:11-6.

17. Peterson EH. Serviceman's poultry health hand book. Falleteville, Arkansas: University of Arkansas; 1972.

18. Vetterlein W, Lieberman H. Die Morphologische Entwicklung des Virus der Transmissiblen Gastroenteritis im Vergleich mit anderen Viren. Arch Exp Vet Med. 1970;24:549-58.

19. Maxler GL. Lesiones of transmissible gastroenteritis in the pigs as determinated by scanning electron microscopy. Am J Vet Res. 1972;33:1323-8.

20. Young GS, Underdahl NR, Hinz RW. A serum neutralization test for TGE. Cornell Vet. 1953;43:561-6. 